\title{
PLURALISME BUDAYA DALAM REFORMASI HUKUM DI INDONESIA
}

\author{
Oleh: Musleh Harry*
}

\begin{abstract}
Setiap produk peraturan perundang-undangan yang telah dikeluarkan atau disahkan, seharus ditaati oleh masyarakat Indonesia baik secara individual maupun secara kelompok. Agar setiap peraturan yang dikeluarkan tersebut di taati oleh masyarakat maka harus memenuhi beberapa syarat, yaitu: peraturan yang akan dan/atau dibuat itu harus benar-benar mengakomudasi apa yang di inginkan oleh masyarakat yang beragam budaya tersebut. Akan tetapi hal-hal yang diakomudasi itupun harus yang tidak menggangu perkembangan masyarakat, bangsa dan negara.
\end{abstract}

\section{Kata Kunci: Pluralisme, Budaya, Hukum, Reformasi}

\section{Pendahuluan}

Negara Indonesia adalah negara kepulauan yang terdiri dari berbagai suku dan adat istiadat, setiap suku memiliki kebudayaan yang beraneram pula, meskipun dasar serta sifatnya adalah satu, yaitu ke-Indonesiaannya. Oleh karena itu. Maka adat dan kebudayaan bangsa Indonesia itu dikatakan merupakan "Bhinneka" (berbeda-beda di daerah suku-suku bangsanya), "Tunggal Ika" (tetapi tetap satu juga) menuju ke sifat ke-Indonesiaan itu. Oleh karena itu Indonesia dikatakan sebagai negara yang memiliki kemajemukan kebudayaan.

Jika berbicara mengenai budaya maka akan tekait dengan suatu aturan atau hukum, karena sesuai dengan adegium yang mengatakan bahwa "dimana ada masyarakat di situ ada hukum". hal ini menandakan bahwa adanya keberagaman budaya dalam masyarakat membuktikan juga terdapat keanekaragaman hukum yang berlaku dalam masyarakat Indonesia. Hukum dalam masyarakat tersebut adalah biasa dikenal dengan adat istiadat atau hukum adat. Hukum tersebut dalam masyarakat berfungsi sebagaimana halnya hukum positif, karena hukumpun bersumber dari nilai-nilai budaya masyarakat. Sedangkan nilai budaya oleh masyarakat dijadikan pedoman yang memberi arah dan orientasi kepada warga masyarakat.

Secara sederhana pengertian pluralisme budaya adalah terdapatnya lebih dari satu sistem budaya dalam suatu masyarakat, kemudian sistem budaya tersebut

\section{Penulis Pembartu Dekan II Fakultas Syariah UIIS Malang}


oleh anggota masyarakat sama-sama diberlakukannya. Pluralisme budaya dapat muncul karena adanya berbagai macam suku bangsa dan juga karena adanya proses perubahan masyarakat.

Pengertian pluralisme budaya di atas di dasarkan pada pernyataan Ghe dan Gomes sebagaimana yang dikutip Nurjaya (dalam Masimbaow, 2000: 208) yang menegaskan bahwa kemajemukan budaya berpangkal pada berbagai suku minoritas pribumi ( yang dikenal sebagai suku asli) dan itu semua menjadi salah satu ciri khas wilayah Asia Tenggara. Dari pendapat tersebut dapat dimengerti bahwa pluralisme budaya identik dengan kemajemukan budaya.

Uraian di atas menjelaskan bahwa hukum itu berasal dari nilai budaya, sehingga hukum di Indonesia dalam arti hukum nasional itu bersumber dari nilai budaya bangsa yang sudah ada dan berkembang hingga sekarang (Toeti Herart, 1997: 18).

Pada masa reformasi sekarang ini banyak diadakan perubahan diberbagai aspek kehidupan, baik perubahan terjadi pada prilaku masyarakat, tatanan pemerintahan maupun perubahan itu terjadi pada hukum. Perubahan pada aspek hukum itu dilakukan pada cara pembuatannya maupun pada penegakannya. Masalahnya sekarang apakah perubahan di dalam aspek hukum terutama dalam pembuatan hukum sudah berpegang pada landasan pluralisme budaya ? sepintas bisa kita lihat, bahwa kenyataannya sekarang memang ada perubahan yang dulu cara maupun pembentukan hukum tidak memperhatikan kebutuhan masyarakat apalagi harus berlandaskan pada kemajemukan budaya (Masinambow, 2000: 5).

Sebelum menjawa pertanyaan di atas sebaiknya kita lihat bagaimana keterkaitan antara pluralisme budaya dengan pluralisme hukum yang ikuti. Hukum adalah manifestasi makna-makna simbolik dari perilaku sosial sebagaimana yang tampak dalam interaksi antar anggota masyarakat. Hukum sekaligus dianggap sebagai pola perilaku sosial yang terlembaga dan aksis sebagai variabel sosial yang empirik (Sidharta, 1999: 159). Hukuman terbentuk dan berkembang sebagai produk yang sekaligus mempengaruhi, dan karena itu mencerminkan dinamika proses interaksi yang berlangsung terus menerus antara berbagai faktor kenyataan masyarakat (aspirasi manusia, keyakinan, keagamaan, sosial, ekonomi, politik, moral, kondisi kebudayaan dan peradaban dalam batas-batas lingkungan alamiah) satu dengan lainnya yang berkonfrontasi dengan kesadaran dan penghayatan manusia terhadap kenyataan kemanusiaan itu yang berakar dalam pandangan hidup yang dianut serta kepentingan dan kebutuhan nyata manusia (Sidharta, 1999: 189).

Dari uraian di atas, timbul pertanyaan besar bagi kita semua yaitu tentang bagaimana keberadaan pluralisme budaya dalam pembentukan pada masa reformasi sekarang ini ?

Plurarisme budaya mengisi pluralisme hukum, atau setidaknya pluralisme budaya dapat mengisi suatu sistem hukum, karena hukum yang baik selalu berbasis pada struktur sosial (budaya), padahal kenyataannya dalam struktur sosial 
masyarakat modern seperti saat telah terjadi kemejemukan budaya.

Berbicara mengenai reformasi hukum di Indonesia bukan hal baru lagi. Setelah Indonesia merdeka telah dipacu kearah itu, misalnya : berupaya membuat undangundang yang sesuai dengan alam Indonesia sebagaimana diamanatkan oleh teks proklamasi itu sendiri. Bahwa bangsa mulai saat telah bebas dari penjajahan apapun dan menuju alam ke-Indonesiaan termasuk juga hukumnya. Contohnya UUPA yang telah dibuat sejak tahun 1960 oleh bangsa Indonesia guna mengatur, menata penggunaan tanah khusus bagi masyarakat Indonesia, di mana sebelumnya pengaturan mengenai tanah diatur dengan dua macam hukum (dualisme hukum tanah).

Reformasi hukum kembali marah dan dibicarakan sejak terjadinya pergantian kekuasaan dari Orde Baru ke pemerintahan transisi saat itu. Tuntutan reformasi di bidang hukum ini dikukuhkan dalam sidang Istimewa MPR tahun 1998 melalui Tap MPR RI No. X/MPR/1998 tentang Pokok-Pokok Reformasi dalam rangka penyelamatan dan normalisasi kehidupan nasional sebagai haluan negara. Agenda reformasi yang dirumuskan dalam sidang Istimewa MPR tersebut merupakan tuntutan masyarakat yang harus dilaksanakan sebagai wujud pelaksanaan dan perjanjian masyarakat dengan wakil rakyat. Isi perjanjian dibidang reformasi hukum yang akan dituntut masyarakat kepada wakil-wakilnya di DPR dan MPR adalah terbentuknya peraturan perundang-undangan yang melindungi keberadaan dan hak masyarakat sebagai hak pribadi dan anggota masyarakat di negara yang berdasarkan pada hukum. Semua ini mengingat bahwa masih banyak hal-hal yang tidak sesuai dan melindungi hal rakyat terutama masyarakat hukum adat.

Salah satu langkah untuk memenuhi keinginan masyarakat diwujutkan dalam TAP MPR RI No. IV/MPR/1999 tentang GBHN Th. 1999-2000. Di dalam GBHN Bab IV Arah Kebijakan dibidang hukum termuat pengakuan dan penghormatan terhadap hukum agama dan hukum adat, hal ini sebagai jawaban permulaan akan kebutuhan masyarakat terutama dalam prulalisme kebudayaan, karena bagaimanapun juga unifikasi hukum sangat sulit dilaksanakan secara merarta, karena efektifitasnya akan hilang bila menyangkut hukum kekluargaan seperti perkawinan waris.

Jadi di sini terlihat prulalisme budaya mulai diberi tempat. Yaitu dengan termuatnya pengakuan dan penghormatan hak adat dan dalam penerapannya mulai terlihat dalam pembuatan nernagai Undang-Undang, salah satunya Undang-Undang No. 41 Tahun 1999 tentang kebutuhan dimana dalam Bab IX mengenai masyarakat dalam hukum adat. Dalam Bab itu Pasal 67 dikatakan

1. Masyarakat hukum adat sepanjang menurut kenyataannya masih ada dan diakui kebeadaannya berikut.

- Melakukan kegiatan pengelolaan hutan untuk pemenuhan kebutuhan seharihari masyarakat hukum adat yang bersangkutan. 
- Melakukan kegiatan pengelolahan hutan berdasarkan hukum adat yang berlaku dan tidak bertentangan dengan undang-undang dan

- Mendapatkan pembedayaan dalam rangka meningkatkan kesejahteraan.

Ini berarti sudah ada ruang terhadap prulalisme budaya. Sekarang bagaimana pelaksanaannya dalam masyarakat. Kita harapkan bahwa pernyataan-pernyataan mengenai prulalisme itu dilaksanakan secara konsekuen dan tidak dimandulkan.

\section{Reformasi Hukum Harus Berlandaskan Pada Pluralisme Budaya}

Von savigny berpendapat bahwa: hukum ditemukan tidak dibuat, pertumbuhan hukum merupakan suatu proses yang tidak disadari dan bersifat organis sehingga perundang-undangan dianggap kurang penting dibandingkan dengan adat istiadat; perkembangan bertolak dari hubungan-hubungan hukum yang mudah dipahami dalam masyarakat primitif ke dalam hukum yang lebih konpleks dalam peradaban yang modern. Setiap masyarakat mengembangkan setiap hukum kebiasaannya sendiri, karena mempunyai bahasa, adat istiadat dan konstitusi yang khas, sehingga volkgeist dari suatu bangsa akan terlihat dalam hukumnya (Hermayulis dalam Masinambow, 2000: 88).

Dalam masyarakat modem hukum harus dibentuk/dibuat, bahkan harus terjangkau ke depan agar dapat menjalankan fun gsinya sebagai" social enggeneering". Kaidah hukum modern tidak semata-mata ditemukan dalam masyarakat. Hanya saja reformasi hukum diupayakan seoptimal mungkin agar selalu berlandaskan pada masyarakatnya.

Chambliss dan Siedman(Rahardjo, 1984: 49) menegaskan bahwa hukum perlu dibentuk/dibuat. Berdasarkan model masyarakat pembentuk hukum, pembuatan (reformasi) hukum diklasifikasikan menjadi 2 , yaitu dibuat:

1. Berlandaskan basis kesepakatan tentang nilai-nilai (value concensusu).

Pada model pertama ini reformasi/perubahan hukum merupakan pencerminan dari nilai-nilai yang disepakati oleh masyarakat. Masalah yang dihadapi dalam model perubahan hukum ini hanyalah cara untuk menetapkan nilai-nilai yang akan diberlakukan secara umum di masyarakat. Menurut Van Valenhoven menyatakan bahwa dalam masyarakat sederhana hukum adat dapat diucapkan begitu saja melalui kepala-kepala persekutuan hidup setempat atau mungkin hukum adat tersebut hanya lahir melalui keputusan-keputusan yang dibuat oleh para masyarakat sendiri (Rahardjo, 1976: 26-28).

2. Model Konflik

Dalam masyarakat tipe ini, pembentukan atau dalam mereformasi hukum bertumpu pada adanya tekanan-tekanan terhadap anggota masyarakat tertentu oleh masyarakat lainnya. Perubahan dan konflik dalam masyarakat tipe ini dianggap wajar. Nilai-nilai yang berlaku dalam masyarakat selalu berada dalam situai konflik antara satu anggota masyarakat dengan anggota lainnya, keadaan 
yang demikian berpengaruh pada pembuatan hukum. Menurut Schuyt, pembentukan hukum dalam masyarakat yang di dalamnya selalu terjadi konflik dapat terjadi 2 kemungkinan, yaitu: pembuatan hukum hanya dianggap sebagai sarana untuk mencairkan pertentangan (conflictoplossing); dan pembuatan hukum dianggap sebagai tindakan yang memperkuat terjadinya pertentangan (conflicversterking). Dengan demikian pembuatan/perubahan hukum dalam masyarakat tipe ke dua hanya merupakan semacam endapan pertentangan yang terdapat dalam masyarakat. Maksud pernyataan ini, bahwa konflik antar anggota masyarakat hanya diselesaikan melalui hukum secara semu, sehingga hukum yang akan datang harus dapat mendapatkan pertentangan yang pasca pembentukan hukum yang berlalu.

Pendapat Chambliss dan Siedman tersebut dapat penulis terima, karena secara nyata bahwa dalam tatapan masyarakat Indonersia seperti saat ini jelas akan berlaku sistem pembentukan hukum yang model kedua. Menurut penulis pembentukan hukum model pertama hanya terdapat dalam masyarakat yang kehidupannya masih sederhana.

Dari uraian di atas dapat disimpulkan bahwa pembentukan atau dalam mereformasi hukum di Indonesia harus bertumpu pada keragaman budaya (Pluralisme budaya) bangsa Indonesia. Hukum yang dibuat harus berbasis pada setruktur sosisal masyarakat Indonesia (Rahardjo, 1976 : 18) sehingga hukum yang dibentuk dapat memenuhi tuntutan hukum modern sebagaimana yang dikemukakan oleh Anthony Allot (Hermayulis dalam Masinambow, 2000 : 96), yaitu mempunyai sifat prefentif, dan fasilitatif.

Pengertian struktur sosial dalam konteks hukum adalah bentuk pengorganisasian suatu kehidupan masyarakat sehingga bentuk tersebut terkait dengan cara menentukan hubungan antara lembaga-lembaga didalam masyarakat, cara-cara membuat pelapisan sosial, dan cara-cara menyusun kaidah-kaidah sosial (Rahardjo, 1976 : 19). Dengan hukum yang berbasis pada setruktur masyarakat berarti hukum yang dibentuk dapat selaras (bukan sama) dengan pendapat Vog Suvigny yang mengemukakan bahwa hukum merupakan pencerminan "volkgeist" (jiwa rakyat). Satjipto Rahadjo menegaskan bahwa Hukum sebagai sarana kontrol sosial sarat dengan muatan nilai-nilai yang dijunjung tinggi oleh masyarakatnya sehingga suatu model hukum sebenarnya harus merupakan suatu tatanan yang "sosial sentris" (Rifat dalam Masinambow, 2000 : 154).

Satu hal yang harus dipikirkan oleh pembentuk hukum (pembentuk UU), struktur sosial dan "volkgeist" yang mana yang dapat dijadikan basis pembentukan hukum di Indonesia ?, dan apakah hukum adat yang ada di Indonesia mampu mengimbangi kecepatan perkembangan masyarakat global ?

Sebagai langkah awal pemahaman atas permasalahan tersebut, perlu disikapi 
bahwa secara umum hukum adat di Indonesia mengutamakan bentuk-bentuk dari konsep harmoni, sikap paternalistik, pandangan negaif terhadap konflik, dan penyelesaian sengketa secara damai. Pada sisi lain perkembangan hukum adat mengalami kontinuitas yang terputus-putus karena masuknya bangsa penjajah yang mengakibatkan kenacetan perkembangan struktur sosial, bahwa kedatangan bangsa barat telah meluluhlantakkan sendi-sendi (basis) sosial dan merubah struktur sosial (Rahardjo, 1976 : 22). Indonesia dipaksa memakai hukum barat melalui kolonialisasi sehingga dalam masyarakat sering kali terjadi kepincangan antara hukum dengan struktur masyarakat Indonesia.

Secara substansial adat istiadat meliputi norma dan hukum. Keduanya bersumber pada nilai budaya yang merupakan tingkatan yang paling tinggi dan paling abstrak. Hukum di dalam realitas harus dilihat sebagai perwujudan dan pencerminan dari setruktur masyarakat tempat

\section{PENUTUP}

Indonesia sebagai negara yang memiliki kemajemukan budaya, oleh karena itu pemerintah dan institusi lain terkait harus peka dengan keadaan ini terutama dalam penyusunan/pembuatan hukum karena kita ketahui bahwa hukum itu tumbuh dan berkembang dari masyarakat.

Setiap produk peraturan perundang-undangan yang telah dikeluarkan atau disahkan, seharus ditaati oleh masyarakat Indonesia baik secara individual maupun secara kelompok. Agar setiap peraturan yang dikeluarkan tersebut di taati oleh masyarakat maka harus memenuhi beberapa syarat, yaitu: peraturan yang akan dan/atau dibuat itu harus benar-benar mengakomudasi apa yang di inginkan oleh masyarakat yang beragam budaya tersebut. Akan tetapi hal-hal yang diakomudasi itupun harus yang tidak menggangu perkembangan masyarakat, bangsa dan negara.

Setelah dikeluarkan atau disahkan peraturan tersebut, agar dapat berjalan dengan baik dalam arti dipatuhi oleh masyarakat luas, harus dilengkapi dengan penegak hukum yang proposional dan benar-benar mempunyai jiwa penegak sehingga peraturan yang dijalan dapat terlaksana secara konsekuen dan akan tercapai keadilan, baik menurut peraturan itu sendiri maupun menurut masyarakat.

\section{DAFTAR PUSTAKA}

Fadjar. Abdul Mukthie, (2000), "Visi dan Misi Reformasi Hukum dan Keadilan" dalam Mukthie Faddjar, Kapita Selekta Politik Hukum, Program Pasca Sarjana. Universitas Brawijaya, Malang, 2000.

Marzuki, Laica (2000), "The Problem of Social and Culture Diversity in Reforming National Low Towart A New Civil Society" dalam Mukthie Fadjar 
(Ed), Kapita Selekta Politik Hukum, Program Pascasarjana, UNIBRAW 2000.

Masinambow, E.X.N, Ed., (2000), Hukum dan Kemajemukan Budaya: sumbangan karangan untuk menyambut Hari Ulang Tahun ke 70 Prof. Dr. T.O. Ihrowi, Yayasan Obor Indonesia, Jakarta.

Noerhadi, Toeti Herarti (1997), "Urgensi Kebudayaan sebagai Materi Hukum Nasional”, dalam Artidjo Al Kostar (Ed), Identitas Hukum Nasional, 1997.

Rahadjo Satjipto, (1999), "Masalah Kebhinekaan Sosisal Budaya Dalam reformasi Hukum Menuju Masyarakat Kewargaan", dalam Mukthie Faddjar, Kapita Selekta Politik Hukum, Program Pasca Sarjana, Universitas Brawijaya, Malang, 2000.

Alumni, Bandung.

1976. Hukum, Masyarakat dan Pembangunan, 1979. Hukum, dan Perubahan Masyarakat,

Alumni, Bandung. 1984. Hukum, dan Masyarakat, Alumni, Bandung.

Sidharta, B. Areif, 1999. Refleksi tentang Struktur Ilmu Hukum, Mndar Maju, Bandung. 